\title{
The Effectiveness of Health Promotion on Knowledge of Mothers about Acute Respiratory Infections (ARI) in Mipiran Village, Padamara Public Health Center
}

Corresponding Author:

Lu'lu Nafisah

luluhatta@gmail.com

Received: 26 December 2018

Accepted: 23 February 2019

Published: 7 March 2019

Publishing services provided by

Knowledge E

(c) Lu'lu Nafisah et al. This article is distributed under the terms of the Creative Commons

Attribution License, which permits unrestricted use and redistribution provided that the original author and source are credited.

Selection and Peer-review under the responsibility of the 2 nd International Meeting of Public Health 2016 Conference Committee.

\section{G OPEN ACCESS}

\section{Lu'lu Nafisah $^{1,2}$, Siti Herwanti ${ }^{2}$, Dwi Annisa Fajria ${ }^{2}$, Avi Nurdinia ${ }^{2}$, Ajeng Prastiwi ${ }^{2}$, Michika Adisa ${ }^{2}$, Irfan Febriary ${ }^{2}$, Nurul Akmalia², and Dilla Fadhilah² \\ ${ }^{1}$ Postgraduate Student Faculty of Public Health, Universitas Indonesia, Depok, Indonesia ${ }^{2}$ Department of Public Health, University of Jenderal Soedirman, Purwokerto, Indonesia}

\section{Abstract}

Acute Respiratory Infections (ARI) was the first rank of 10 central outpatient diseases in Padamara Public Health Center, Purbalingga in 2013. Miran village was the five most ARI cases in Padamara Public Health Center (7.48\%) with the highest number of cases are among children under-five (26.04\%). Factors related to the incidence of ARI among children under-five in Mipiran village was a lack of knowledge of mothers about ARI. This study aimed to determine the effectiveness of health promotion in Mipiran village to increase understanding of prevention of ARI. This was a study using quasi-experimental with one group pre-test and post-test design. The population was 78 mothers and samples taken by purposive sampling with a sample size of 18 mothers. Data analysis was performed using a paired t-test. The variable measured was knowledge about ARI. The results showed there were differences in the respondent's knowledge after health promotion at pre-test and post-test with p-value $(0.00)<0.05$. Health promotion can increase understanding of respondents significantly. Information about childhood illnesses and how to prevent it need to be delivered to the mothers either through print media or education activities.

Keywords: ARl; health promotion; under-five children

\section{Introduction}

Acute Respiratory Infections (ARI) was the first rank of 10 central outpatient diseases in Padamara Public Health Center, Purbalingga in 2013. Based on the report for Disease Control and recapitulation of ARI cases in 2013 in the Padamara Public Health Center, Mipiran village was the 5th largest ARI cases from 14 villages in Padamara Subdistrict (7.48\%), comprising $26.04 \%$ of ARI cases at age 0 -5 years, $20.96 \%$ at age $5-11$ years, $9.58 \%$ at age $12-25$ years, $22.75 \%$ at age $26-45$ years, $13.77 \%$ at age $46-64$ years, and 6 , 
$9 \%$ at age 65 years. Thus, the highest number of cases in the Mipiran village was found in infants. Based on sex, a number of ARI cases in girls was (67.06\%) much more than boys (32.94\%).

According to Prabowo (2012), under-five children were the group that had a weak immune system so that the toddlers were the most vulnerable to various diseases, especially ARI. According to research conducted by Hasan (2012), factors that affected the occurrence of ARI among under-five children were the history of exclusive breastfeeding, lighting, the type of wall, humidity, and temperature. Meanwhile, according to research conducted by Marhamah et al. (2013), it showed that the immunization status and whereabouts of family members who smoke in the home affect the prevalence of ARI among under-five children.

The results of the analysis of factors related to the occurrence of ARI among under-five children in the Mipiran village, Padamara Subdistrict identified on the activities of field learning practice in 2014 showed that the low knowledge of mothers about ISPA was related to ARI. The results of research conducted by Sulistyoningsih and Rustandi (2011) in DTP Jamanis public health center concluded that the mother's level of knowledge related to ARI among under-five children. The mother's level of expertise about ARI described the form and manner of care to children affected by ARI (Maramis et al. 2013).

Control of respiratory diseases according to Ministry of Health (2005) conducted in several ways: they were health education prioritized at mothers, enhanced case management, and immunization. Health education was one way to increase knowledge. Notoatmodjo (2007) stated the majority of human knowledge gained through training, personal experience, other people, mass media, and the environment. Individual learning can upgrade directly or indirectly. Direct method was expressed by socialization, coaching, counseling, and others while the indirect way used the provision of media such as leaflets, posters, stickers, and more.

Based on the background, research was conducted to determine the effectiveness of health promotion for increasing knowledge of mothers about ARI among under-five children in Mipiran village, Padamara Public Health Center.

\section{Methods}

This research used quasi-experimental with one group pre-test and post-test design. The sampling technique used was purposive sampling with inclusion criteria mothers whose children within the last three months exposed ARI and following the health promotion from beginning to end as many as 18 people. Analysis of the data used paired sample t-test. The variables measured were the knowledge of mothers about ARI. The 
research conducted onNovember $4^{\text {th }} 2014$ at the Mipiran village Hall, Padamara Public Health Center. Health promotion methods were lectures and discussions about ARI among under-five children.

\section{Results}

\subsection{Characteristics of respondents}

Characteristics of respondents by age and occupation as shown in Table 1 below:

TABLE 1: Characteristics of Respondents.

\begin{tabular}{|c|c|}
\hline Characteristics & Category \\
\hline \multirow[t]{4}{*}{ Age (years) } & Late adolescence \\
\hline & Early adulthood \\
\hline & Late adulthood \\
\hline & Total \\
\hline \multirow[t]{3}{*}{ Occupation } & Housewife \\
\hline & Employee \\
\hline & Total \\
\hline
\end{tabular}

\begin{tabular}{|c|}
\hline $\mathbf{n}$ \\
\hline 8 \\
\hline 9 \\
1 \\
\hline 18 \\
\hline 16 \\
\hline 2 \\
\hline 18 \\
\hline
\end{tabular}

\begin{tabular}{|c|}
\hline$\%$ \\
\hline 44.4 \\
\hline 50.0 \\
\hline 5.6 \\
\hline 100.0 \\
\hline 88.9 \\
\hline 11.1 \\
\hline 100 \\
\hline
\end{tabular}

Table 1 showed that the majority of respondents was classified at the age of early adulthood (50.0\%) and homemakers (88.9\%).

\subsection{Univariate analysis}

TABLE 2: Results of Knowledge Pre Test and Post Test.

N
Max.
Min.
Median
Mean

\begin{tabular}{|c|}
\hline pre test \\
\hline 18 \\
\hline 12 \\
\hline 4 \\
\hline 8 \\
\hline 7.78 \\
\hline
\end{tabular}

\begin{tabular}{|c|}
\hline post test \\
\hline 18 \\
15 \\
6 \\
12 \\
12.28 \\
\hline
\end{tabular}

According to the table 2 , there were differences in the maximum value of the respondent at the time of pre-test and post-test, pre-test value at the time amounted to 12 whereas the value at the time of posttest by 15 . The minimum cost at the time of pre-test and post-test increased, the minimum value of pretest was 4 while at the post-test, it was 6. The median value in the pre-test and post-test increased, shown by 8 of pretest and 12 of post-test score. The cost of the pre-test and post-test has risen during the pre-test was 7.78 and post-test was 12.28 . 


\subsection{Bivariate analysis}

TABLE 3: Results of Paired T-Test.

\begin{tabular}{|c|c|c|c|}
\hline & T & p-value & Conclusion \\
\hline Knowledge pre-test $\times$ post test & -7.628 & 0.000 & Significant \\
\hline
\end{tabular}

Based on the results of Paired T-Test, it was obtained by t-test knowledge of ARI (pretest and post-test) of -7.628 with $\alpha=0.05$, and obtained $p$-value $<0.05$. So, there were significant differences in knowledge before and after health promotion.

\section{Discussion}

Participatory extension aims to increase knowledge of mothers about ARI among underfive children, especially the causes and risk factors of ARI and prevention. Based on the analysis with paired T-test, it was obtained $p$-value $<0.05$. So, there were significant differences in knowledge before and after health promotion, showing that there was an increased knowledge of the participants. Participants enthusiastically followed health promotion, listened to the material presented about ARI, shared experiences when caring for sick children, and were active to ask questions.

The results were consistent with the theory of WHO in Notoatmodjo (2007), stating that the provision of information was one behavior change strategy in the health program where domain knowledge was essential for the formation of a person's actions. Azwar (2010) mentioned knowledge had an indispensable role in shaping the attitudes and behavior of people which determined the quality of public health. According to Mubarak (2010), seven factors affecting a person's knowledge were: education, employment, age, interests, experiences, culture, and the ease to obtain information.

Health education is part of the whole effort toward health, which focuses on healthy lifestyle changes. Health education does not replace health care but is conducted to improve the utilization of existing health services, health education to encourage healthy behaviors, prevent illness, cure disease, and help cure diseases (Irianto 2014).

Suprapto (2004) stated that the extension by using the lecture method occured where the implementation of two-way communication occurred face to face counseling so that counselors could directly determine the response and the interaction between counselor and participant activities. The results of the study by Utari et al. (2014) cited an increase in knowledge about ISPA once held health education in the family. This was supported by research results Kapti (2010) stating that there was a significant difference 
of knowledge and mother attitude in the management of infants with diarrhea after counseling between the control group and the intervention group.

\section{Conclusions}

Health promotion to mothers about ARI gave effects to increase knowledge of mothers, indicated by the paired t-test results $p$-value $<0.05$.

\section{Acknowledgments}

This paper was contributed by field practice team from the department of public health, University of Jenderal Soedirman, held from 2013 - 2014 in Mipiran village, Padamara Public Health Center. Thank Dwi Annisa Fajria, Michika Adisa, Ajeng Prastiwi, Nurul Akmalia, Irfan Febriary, Avi Nurdinia, and Dilla Fadhilah as the team and Siti Harwanti as a supervisor, and also thank for village official and Mipiran people for their willingness to get involved in this research.

\section{References}

[1] Azwars, S. 2010. Sikap Manusia, Teori, dan Pengukuran. Yogyakarta: Pustaka Pelajar.

[2] Depkes RI. 2005. Pedoman Pemberantasan Penyakit Infeksi Saluran Pernafasan Akut (ISPA). Jakarta: Direktorat Jenderal PPM dan PLP.

[3] Hasan, N R. 2012. Faktor-faktor yang Berhubungan dengan Kejadian ISPA Pada Balita di Wilayah Kerja UPTD Kesehatan Luwuk Timur, Kabupaten Banggai, Provinsi Sulawesi Tengah Tahun 2012. Skripsi. Fakultas Kesehatan Masyarakat. Universitas Indonesia.

[4] Irianto, K. 2014. IImu Kesehatan Masyarakat. Bandung: Alfabet.

[5] Kapti, R. E. 2010. Efektifitas Audiovisual Sebagai Media Penyuluhan Kesehatan Terhadap Peningkatan Pengetahuan dan Sikap Ibu dalam Tatalaksana Balita dengan Diare Di Dua Rumah Sakit Kota Malang. Tesis. Universitas Indonesia. http:Iontar.ui. ac.id/file?file=digital/137097-T\{\%\}20Rinik\{\%\}20Eko\{\%\}20Kapti.pdf.

[6] Maramis, P.A., A.Y Ismanto, dan A Babakal. 2013. Hubungan Tingkat Pendidikan dan Pengetahuan Ibu tentang ISPA dengan Kemampuan Ibu Merawat Balita ISPA. ejournal keperawatan (e-Kp) 1 (1). http://ejournal.unsrat.ac.id/index.php/jkp/article/ view/2226/1783 (Accessed October 22, 2016). 
[7] Marhamah, A. Arsunan Arsin, dan Wahiduddin. 2013. Faktor yang Berhubungan dengan Kejadian ISPA Pada Anak Balita di Desa Bontongan Kabupaten Enrekang. http://repository.unhas.ac.id/bitstream/handle/123456789/4602/ MARHAMAH_K11109323.pdf?sequence=1 (Accessed October 22, 2016).

[8] Mubarok, W.I. 2010. IImu Kesehatan Masyarakat: Teori dan Aplikasi. Jakarta: Salemba Medika.

[9] Notoatmodjo, S. 2007. Promosi Kesehatan dan Ilmu Perilaku. Jakarta: Rineka Cipta.

[10] Probowo, GS., V.Y Pohan., dan E Sulistyowati. 2012. Hubungan Antara Status Gizi dengan kejadian ISPA pada balita di Desa Cepokomulyo Wilayah kerja Puskesmas Gemuh I Kabupaten Kendal. Keperawatan Vol 1, No 1 (2012). http://jurma.unimus.ac. id/index.php/perawat/article/view/74/74 (Accessed October 22, 2016).

[11] Sulistyoningsih, $\mathrm{H}$ dan Rustandi, R. 2011. Faktor-Faktor yang Berhubungan dengan Kejadian ISPA pada Balita di Wilayah Kerja Puskesmas DTP Jamanis Kabupaten Tasikmalaya tahun 2010. Skripsi. Fakultas Kesehatan Masyarakat. Universitas Siliwangi.

[12] Suprapto, T. dan Fahrianoor. 2004. Komunikasi Penyuluhan dalam Teori dan Praktek. Yogyakarta: Arti Bumi Intaran.

[13] Utari, W, Arneliwati, dan N Riri. 2014. Efektifitas Pendidikan Kesehatan Terhadap Peningkatan Pengetahuan Keluarga Tentang Infeksi Saluran Pernapasan Akut (ISPA). jom.unri.ac.id/index.php/JOMPSIK/article/download/3489/3385 (Accessed October 24, 2016). 